\title{
Penerapan Model Pembelajaran TPS (Think Pair Share) pada Materi Negara Maju dan Negara Berkembang untuk Meningkatkan Kemampuan Bertanya dan Hasil Belajar Siswa
}

\author{
Sunarto \\ SMP Negeri 1 Nusawungu, Cilacap \\ Rawabangus, Danasri, Nusawungu, Rawabangus, Danasri, Nusawungu, \\ Kabupaten Cilacap, Jawa Tengah \\ Email: bdmartono7@gmail.com
}

\begin{abstract}
Abstrak
Penelitian ini bertujuan untuk meningkatkan kemampuan bertanya dan hasil belajar siswa pada materi sistem gerak pada manusia di kelas IX D SMP Negeri 1 Nusawungu dengan model pembelajaran kooperatif tipe TPS (Think Pair Share). Penelitian ini merupakan jenis Penelitian Tindakan Kelas (PTK) yang merupakan suatu penelitian yang dilakukan secara sistematis reflektif terhadap tindakan yang dilakukan oleh guru sebagai peneliti, mulai dari perencanaan, pelaksanaan, sampai dengan penilaian untuk mempebaiki kondisi pembelajaran. Dalam penelitian tindakan kelas ini peneliti menggunakan dua siklus, yang masing-masing siklusnya terdiri dari empat tahap yaitu rencana (planning), tindakan (action), observasi (observation), dan refleksi (reflection). Instrumen penelitian berupa tes yang bertujuan untuk mengetahui hasil belajar siswa dan non tes yang berupa lembar observasi yang diisi oleh kolaborator, dan lembar angket motivasi siswa yang diisi oleh siswa. Subjek penelitian ini adalah siswa kelas IX D SMP Negeri 1 Nusawungu yang berjumlah 32 siswa. Teknik analisis data yang digunakan untuk proses penilaian adalah deskriptif kuantitatif untuk mengetahui peningkatan hasil belajar siswa, dan deskripsi kualitatif untuk mengetahui kemampuan bertanya siswa. Hasil penelitian tindakan kelas ini berupa penerapan model pembelajaran TPS (Think Pair Share) yang memberikan peningkatan terhadap kemampuan bertanya dan hasil belajar siswa dari siklus I, siklus II secara berurutan yaitu memliki persentase kelulusan sebesar $25 \%$ menjadi $97 \%$ sedangkan kemampuan bertanya siswa dari $36 \%$ menjadi $92 \%$. sehingga dapat disimpulkan bahwa penerapan model pembelajaran tipe TPS dapat meningkatkan kemampuan bertanya dan hasil belajar siswa.
\end{abstract}

Kata Kunci : model pembelajaran TPS, kemampuan bertanya, hasil belajar.

\begin{abstract}
This study aims to improve the ability to ask questions and student learning outcomes on material motion systems in humans in class IX D SMP Negeri 1 Nusawungu with cooperative learning model type TPS (Think Pair Share). This research is a type of Classroom Action Research (CAR) which is a research conducted systematically reflective of the actions taken by the teacher as a researcher, ranging from planning, implementing, to assessments to improve learning conditions. In this class action research researchers used two cycles, each of which consisted of four stages: planning, action, observation, and reflection. The research instrument was in the form of a test aimed at finding out student learning outcomes and non-tests in the form of an observation sheet filled out by collaborators, and a student motivation questionnaire sheet filled out by students. The subjects of this study were students of class IX D of SMP Negeri 1 Nusawungu, totaling 32 students. The data analysis technique used for the assessment process is quantitative descriptive to find out the improvement of student learning outcomes, and qualitative
\end{abstract}


descriptions to determine students' asking abilities. The results of this class action research are the application of the TPS (Think Pair Share) learning model that provides an increase in the ability to ask questions and student learning outcomes from cycle I, cycle II sequentially having a percentage of graduation of $25 \%$ to $97 \%$ while the ability to ask students from $36 \%$ to $92 \%$. so it can be concluded that the application of the TPS type learning model can improve the ability to ask questions and student learning outcomes.

Keywords: TPS learning model, the ability to ask questions, learning outcomes.

\section{PENDAHULUAN}

Proses pembelajaran pada dasarnya merupakan pemberian stimulus-stimulus kepada peserta didik untuk menghasilkan respon positif (Hartono, 2013). Pembelajaran aktif adalah proses pembelajaran dimana saat proses belajar mengajar, terjadi interaksi dan komunikasi multi arah baik antar peserta didik, maupun antara peserta didik dan guru. Proses pembelajaran ini menuntut peserta didik untuk mengembangkan kemampuan berfikir dan menyampaikan hasil pemikirannya kepada orang lain. Dalam bidang pendidikan, keberhasilan siswa dalam belajar merupakan harapan semua pihak, salah satunya pada pelajaran IPS. Sebagian besar siswa mengakui bahwa IPS merupakan pelajaran yang sulit.Oleh karena itu perlu diketahui aspek-aspek yang diduga menyebabkan IPS sulit, yang mempunyai hubungan dengan pembelajaran IPS. Agar proses pembelajaran IPS dapat berjalan secara optimal, maka guru dalam pembelajaran IPS, hendaknya banyak memberikan rangsangan kepada siswa sehingga siswa mau berinteraksi dengan lingkungan secara aktif serta mencari dan menemukan berbagai hal dari lingkungan. Berdasarkan hasil observasi yang telah dilakukan di kelas IX D SMP Negeri 1 Nusawungu pada saat pembelajaran, siswa yang mengajukan pertanyaan $12 \%$, mengajukan pendapat $10,1 \%$, dan menjawab pertanyaan $15 \%$. Selain itu juga diperoleh keterangan antara lain metode pengajaran yang dominan digunakan oleh guru adalah metode ceramah yang bersifat informatif sehingga interaksi antar subjek kurang intensif dan mengena. Guru lebih aktif dalam pembelajaran dan dianggap sebagai satu-satunya sumber belajar bagi siswa. Padahal dalam proses belajar mengajar, bertanya memegang peranan yang penting, sebab pertanyaan yang tersusun baik dengan teknik pengajuan yang tepat akan meningkatkan partisipasi siswa dalam kegiatan belajar, meningkatkan minat dan rasa ingin tahu siswa, dan mengembangkan pola berpikir serta belajar aktif siswa (Hasibuan dan Mudjiono : 1985). Oleh karena itu, guru hendaknya memilih dan menggunakan strategi, pendekatan, metode pembelajaran serta model pembelajaran yang tepat sesuai dengan materi yang diajarkan, agar tujuan pembelajaran dapat tercapai secara maksimal. Salah satu 
alternatif pemecahan dalam menghadapi masalah tersebut adalah penggunaan model pembelajaran TPS (Think Pair Share). Karena dalam pembelajaran kooperatif tipe TPS, pada tahap Pair siswa dapat berpikir untuk menyelesaikan pertanyaan yang diajukan guru dengan berdiskusi bersama pasangannya.Selain itu,pada tahap Share siswa berbagi dalam kelas secara keseluruhan sehingga proses pembelajaran berlangsung secara efektif karena memberikan kesempatan kepada siswa untuk mengemukakan pendapatnya, menanyakan kesulitan dalam belajarnya. Berdasarkan uraian permasalahan di atas maka peneliti tertarik untuk mengatasi permasalahan di kelas IX D yaitu meningkatkan kemampuan bertanya dan hasil belajar siswa melalui pembelajaran kooperatif tipe TPS di SMP Negeri 1 Nusawungu. Diharapkan pembelajaran tersebut mampu meningkatkan kemampuan bertanya siswa dan hasil belajar siswa.

Dari latar belakang masalah di atas, maka penulis menemukan beberapa permasalahan, yaitu :

1. Banyaknya siswa yang belum mencapai batas Kriteria Ketuntasan Minimal (KKM).

2. Banyaknya siswa yang masih pasif dalam mengikuti kegiatan pembelajaran.

3. Rendah partisipasi siswa yang aktif dalam pembelajaran IPS, khususnya memahami Negara Maju dan Negara Berkembang.

4. Rendahnya penguasaan siswa terhadap materi prasyarat pembelajaran memahami Negara Maju dan Negara Berkembang.

5. Rendahnya kemampuan guru dalam memvariasikan model dan media pembelajaran IPS.

6. Fokus pembelajaran ada pada guru, sedangkan siswa hanya menerima apa-apa yang diberikan guru tanpa melalui aktivitas dan partisipasi yang berarti.

Dibawah ini akan dipaparkan kajian teori terkait penelitian:

\section{Kemampuan Bertanya}

Bertanya atau mengajukan pertanyaan merupakan suatu cara untuk meminta keterangan atau penjelasan dari sesuatu yang belum diketahui selain menyatakan pendapat, perasaan, mengajukan alasan, mempertegas pendapat, dan sebagainya (Harsanto : 2007). Menurut Wina Sanjaya (2009 : 12) kemampuan bertanya, yakni kemampuan dasar untuk mengajak siswa berpikir mengeluarkan ide dan gagasan yang orisinal melalui bahasa lisan. Dari pengertian tersebut, indikator kemampuan bertanya yaitu menyampaikan pertanyaan, menyampaikan pendapat, menyampaikan jawaban, dan mempresentasikan hasil diskusi atau jawaban. 
Siswa dalam mengajukan pertanyaan mempunyai tujuan. Menurut Hasibuan dan Moedjiono (1985:14) tujuan dari mengajukan pertanyaan antara lain sebagai berikut :

1. Meningkatkan partisipasi siswa dalam kegiatan belajar-mengajar.

2. Membangkitkan minat dan rasa ingin tahu siswa terhadap masalah yang sedang dibicarakan.

3. Mengembangkan pola berpikir dan belajar aktif siswa, sebab berpikir itu sendiri adalah bertanya.

4. Menuntun proses berpikir siswa, sebab pertanyaan yang baik akan membantu siswa agar dapat menentukan jawaban yang baik.

5. Memusatkan perhatian murid terhadap masalah yang sedang dibahas.

\section{Metode TPS (Think Pair Share)}

Metode sederhana tetapi sangat bermanfaat dikembangkan oleh FrankLyman dari University of Maryland. Ketika guru menyampaikan pelajaran kepada kelas, para siswa duduk berpasangan dengantimnya masing - masing. Guru memberikan pertanyaan kepada kelas. Siswa diminta untuk memikirkan sebuah jawaban dari mereka sendiri, lalu berpasangan dengan pasangannya untuk mencapai sebuah kesepakatan terhadap jawaban. Akhirnya, guru meminta para siswa untuk berbagi jawaban yang telah mereka sepakati dengan seluruh kelas (Slavin, 2005: 257). Think-Pair-Share merupakan suatu cara yang efektif untuk membuat variasi suasana pola diskusi kelas. Prosedur yang digunakan dapat memberi siswa lebih banyak waktu berpikir, untuk merespons dan saling membantu (Trianto:2009). Jadi model pembelajaran kooperatif Think-Pair-Share (TPS) adalah model yang memberikan waktu kepada siswa untuk berpikir dan merespon serta saling membantu satu sama lain.

\section{Langkah - Langkah Pembelajaran Kooperatif Tipe TPS}

Menurut Trianto (2009) strategi dalam pembelajaran kooperatif tipe TPS mempunyai langkah - langkah (fase) antara lain sebagai berikut :

a. Langkah 1 : Berpikir (Thingking), Guru mengajukan suatu pertanyaan atau masalah yang dikaitkan dengan pelajaran, dan meminta siswa menggunakan waktu beberapa menit untuk berpikir sendiri mengenai jawaban atau masalah tersebut.

b. Langkah 2 : Berpasangan (Pairing), Guru meminta siswa untuk berpasangan dan mendiskusikan apa yang telah mereka pikirkan. Interaksi selama waktu yang disediakan dapat menyatukan jawaban jika suatu pertanyaan yang diajukan atau menyatukan gagasan bersama telah diidentifikasi. 
c. Langkah 3 : Berbagi (Sharing), Guru meminta pasangan - pasangan untuk berbagi dengan keseluruhan kelas mengenai apa yang telah mereka bicarakan.

2. Kelebihan dan Kekurangan Pembelajaran Kooperatif Tipe TPS. Menurut Lie (2008) Kelebihan pembelajaran kooperatif tipe TPS yaitu :

a. Akan meningkatkan partisIPSsi.

b. Cocok untuk tugas sederhana.

c. Lebih banyak untuk kontribusi masing - masing pasangan atau anggota kelompok.

d. Interaksi lebih mudah.

e. Lebih mudah dan cepat membentuknya.

Adapun kekurangan pembelajaran kooperatif tipe TPS yaitu :

a. Banyak kelompok yang melapor dan perlu dimonitor.

b. Jika ada perselisihan, tidak ada penengah.

Berdasarkan kajian di atas, pengertian pembelajaran kooperatif tipe TPS adalah pembelajaran yang mempunyai tiga fase antara lain berpikir (Thingking), berpasangan (Pairing), dan berbagi (Share) dimana prosedur yang digunakan dapat memberikan siswa lebih banyak waktu berpikir, untuk merespon dan saling membantu satu sama lain.

\section{METODE PENELITIAN}

Penelitian ini dilaksanakan di SMP Negeri 1 Nusawungu, pada siswa kelas IX D semester I pada tanggal 20 Juli sampai dengan 27 Agustus tahun ajaran 2016/2017. Penelitian dilakukan secara kolaborasi antara dua orang guru IPS SMP Negeri 1 Nusawungu. Jumlah siswa di kelas terdiri dari 12 siswa laki-laki dan 20 siswa perempuan. Sedangkan siswa di kelas tersebut memiliki karakteristik yang sama seperti di kelas-kelas yang lain, artinya tingkat kemampuan/prestasi belajar cenderung sama dengan kemampuan/prestasi kelas lainnya. Alasan peneliti mengadakan penelitian di kelas IX D karena kelas tersebut mewakili tingkat kemampuan bertanya kelas rendah. Subjek pada penelitian ini yaitu kelas IX D SMP Negeri 1 Nusawungu tahun pelajaran 2016-2017 dengan jumlah 32 siswa. Jenis penelitian ini adalah penelitian tindakan kelas yang perencanaan kegiatannya dilakukan siklus, dengan masing-masing siklus 2 kali pertemuan dengan alokasi waktu 2 x 40 menit setiap pertemuannya dan diberi tindakan dengan model pembelajaran kooperatif tipe TPS. Kegiatan ini dikatakan berhasil apabila :

1. Kemampuan bertanya siswa meningkat secara signifikan, baik secara kualitatif yang dapat dilihat dari rata - rata skor kemampuan bertanya maupun secara kuantitatif yang 
dapat dilihat dari frekuensi siswa yang melaksanakan setiap indikator kemampuan bertanya.

2. Indikator keberhasilan penelitian bila ketuntasan individual berada di atas KKM yaitu nilai di atas 78 .

\section{HASIL DAN PEMBAHASAN}

Hasil observasi kemampuan bertanya siswa dari siklus I sampai siklus II dapat dilihat pada tabel di bawah ini :

Tabel 1. Rekapitulasi Hasil Observasi Kemampuan Bertanya Kelas IX D siklus I dan II

\begin{tabular}{|c|l|c|c|}
\hline No. & \multicolumn{1}{|c|}{ Aspek yang dinilai } & Siklus I & Siklus II \\
\hline 1 & Aktivitas siswa bertanya & 7 & 15 \\
2 & Aktivitas siswa menyampaikan pendapat & 6 & 15 \\
3 & Aktivitas siswa menyampaikan jawaban & 5 & 16 \\
4 & Aktivitas siswa mempresentasikan jawaban & 5 & 13 \\
Jumlah & & 23 & 59 \\
Persentase & $36 \%$ & $92 \%$ \\
\hline
\end{tabular}

Hasil observasi kemampuan bertanya menunjukkan bahwa kemampuan bertanya siswa meningkat setiap siklusnya. Dari siklus I sampai siklus II yaitu dari skor 21 sampai 39. Hal tersebut tidak terlepas dari peran guru sebagai motivator yang selalu mendorong siswa agar berani mengajukan pertanyaan, mengajukan pendapat, menjawab pertanyaan, dan mempresentasikan jawaban dengan membimbing dan mengarahkan siswa saat mengalami kesulitan saat pembelajaran berlangsung. Sehingga dikatakan pembelajaran kooperatif tipe TPS dapat meningkatkan kemampuan bertanya siswa. Pada setiap siklus dibuat tes evaluasi dengan asumsi bahwa ketika kemampuan bertanya meningkat maka hasil belajar siswa juga meningkat. Data tes hasil belajar siswa dideskripsikan sebagai berikut :

Tabel 2. Rekapitulasi Tes Evaluasi Akhir Siklus

\begin{tabular}{|c|c|c|c|}
\hline \multirow{2}{*}{ No. } & \multirow{2}{*}{ Pencapaian } & \multicolumn{2}{|c|}{ Siklus } \\
\hline & & $\mathrm{I}$ & II \\
\hline 1 & Jumlah & 1636 & 2306 \\
\hline 2 & Rata-rata & 65,44 & 92.24 \\
\hline 3 & Nilai Tertinggi & 92 & 100 \\
\hline 4 & Nilai Terendah & 48 & 74 \\
\hline 5 & Ketuntasan belajar & $25 \%$ & $97 \%$ \\
\hline
\end{tabular}




\section{KESIMPULAN}

Melalui model pembelajaran kooperatif tipe TPS pada pembelajaran IPS pokok bahasan Negara maju dan Negara berkembang di kelas IX D SMP Negeri 1 Nusawungu selama 2 siklus dapat disimpulkan bahwa kemampuan bertanya meningkat secara signifikan dapat dilihat dari skor kemampuan bertanya pada siklus 1 yaitu 23 dengan kriteria kurang baik, skor kemampuan bertanya pada siklus II yaitu 59 dengan kriteria baik. Model pembelajaran kooperatif tipe TPS juga dapat meningkatkan hasil belajar siswa kelas IX D SMP Negeri 1 Nusawungu. Hal tersebut ditunjukkan dengan meningkatnya nilai ratarata siklus I, II yaitu dari 65,44, menjadi 92,24.

\section{SARAN}

Diperlukan berbagai metode pembelajaran kooperatif untuk mewujudkan tujuan belajar siswa

\section{DAFTAR PUSTAKA}

Arikunto, Suharsimi. 2005. Manajemen Penalitian. Jakarta : PT. Rineka Cipta.

Harsanto, Radno. 2007. Pengelolaan Kelas Yang Dinamis. Yogyakarta : Kanesius.

Hasibuan dan Moedjiono. 1985. Proses Belajar Mengajar. Malang : PT. Remaja Rosdakarya.

Lie, Anita. 2008. Cooperative Learning Mempraktikan Cooperative Learning di Ruang Ruang Kelas. Jakarta : PT. Gramedia.

Rohani, Ahmad. 2004. Pengelolaan Pengajaran. Jakarta: PT. Rineka Cipta.

Sanjaya, Wina. 2009. Penelitian Tindakan Kelas. Bandung : Kencana.

Slavin. 2005. Cooperative Learning. London : Allymand Bacon.

Suprijono, Agus. 2009. Cooperative Learning Teori \& Aplikasi Paikem. Yogyakarta : Pustaka Pelajar.

Trianto. 2009. Mendesain Model Pembelajaran Inovatif - Progresif. Surabaya : Kencana. 